\title{
Evaluation of imaging and conventional PAM as a measure of photosynthesis in thin- and thick-leaved marine macroalgae
}

\author{
Hanne Dalsgaard Nielsen ${ }^{1, *}$, Søren Laurentius Nielsen ${ }^{2}$ \\ ${ }^{1}$ School of Life Sciences, Napier University, 10 Colinton Road, Edinburgh EH10 5DT, UK \\ ${ }^{2}$ Department of Environmental, Social and Spatial Change, Roskilde University, PO Box 260, 4000 Roskilde, Denmark
}

\begin{abstract}
The present paper compares light-response patterns of electron transport rate (ETR) measured by imaging and conventional pulse-amplitude-modulated fluorescence (PAM) with that of gross $\mathrm{O}_{2}$ evolution in naturally thin-leaved (Ulva lactuca) and thick-leaved (Fucus serratus) algae, as well as in 1 to 8 cell layer thick 'artificial thalli' built from layers of Enteromorpha intestinalis. At sub-saturating and saturating irradiances imaging ETR/ETR $\mathrm{max}_{\max }$ provided a very accurate reflection of $P / P_{\max }$, which was different in thin and thick algae. There was no effect of tissue thickness on conventional ETR/ETR ${ }_{\max }$, which was unrelated to $P / P_{\max }$ at low irradiances. At super-saturating irradiances, imaging ETR/ETR $R_{\max }$ was reduced significantly compared to $P / P_{\max }$, which instead corresponded to conventional ETR/ETR $\mathrm{max}_{\max }$. Imaging $F_{\mathrm{m}}$ was only related to thallus thicknesses from 1 to 4 cell layers but not beyond. Photoinhibition expressed by imaging PAM in thick thallus may have been compensated for by photosynthesis in deeper cells. Conventional $F_{\mathrm{m}}$ was linearly related to thallus thickness from 1 to 8 cell layers. No photoinhibition was indicated at super-saturating irradiances by conventional PAM and $\mathrm{O}_{2}$ evolution measurements that integrate the photosynthetic performance of the entire thallus of thick algae. At irradiances $<80 \mu \mathrm{mol} \mathrm{m} \mathrm{m}^{-2} \mathrm{~s}^{-1}$, the $\mathrm{O}_{2} /$ conventional ETR ratio was close to 0.25 , whereas it decreased at higher irradiances in both thin and thick macroalgae. The $\mathrm{O}_{2}$ /imaging ETR ratio was $>0.25$ and increased further at super-saturating irradiances, in particular in thin algae. In conclusion, the type of PAM instrument may influence the light response of ETR. Likewise, the thallus thickness may affect the relationship between $\mathrm{O}_{2}$ evolution and ETR. ETR recordings should be treated with caution and regarded as a compliment to $\mathrm{O}_{2}$ measurements, particularly when thick-leaved macroalgae are studied.
\end{abstract}

KEY WORDS: Chlorophyll fluorescence - Electron transport - Brown algae $\cdot$ Light saturation · $\mathrm{O}_{2} /$ ETR ratio $\cdot$ Photosynthesis $\cdot$ Photoinhibition $\cdot$ PAM

\section{INTRODUCTION}

Pulse-amplitude-modulated measurement (PAM) of Photosystem II (PSII) chlorophyll fluorescence has become a universal technique in modern eco-physiology of algae and higher plants and is applied in almost any study that addresses photosynthetic responses of plants and algae to the environment. Methodology and equations that are employed to acquire information about photochemical processes, e.g. the rate of photosynthetic electron transport (ETR), have been re- viewed extensively (White \& Critchley 1999, Maxwell \& Johnson 2000, Kromkamp \& Forster 2003). While calculations of ETR based on PAM measurements of chlorophyll fluorescence are thought to be reliable, the technique refers exclusively to the physiological state of PSII (Genty et al. 1989). For conclusions to be drawn about overall photosynthesis, the PAM technique should be supplemented by measurement of photosynthetic gas exchange (Maxwell \& Johnson 2000). However, PAM is used increasingly as an independent measurement of photosynthesis in aquatic macro- 
phytes and macroalgae (Häder et al. 1998, Gévaert et al. 2003, Gómez et al. 2004, Strain et al. 2006). Therefore, it has become increasingly pressing to understand the correlation between chlorophyll fluorescence and 'real' photosynthesis, i.e. $\mathrm{O}_{2}$ evolution.

Theoretically, gross $\mathrm{O}_{2}$ evolution can be extrapolated from ETR as 4 electrons are excited for every molecule of $\mathrm{O}_{2}$ evolved at PSII. At low irradiances below photosynthetic saturation there is a linear relationship between gross $\mathrm{O}_{2}$ evolution and ETR, and the $\mathrm{O}_{2}$ /ETR ratio is close to 0.25 (Geel et al. 1997, Longstaff et al. 2002, Figueroa et al. 2003, Beer \& Axelsson 2004). At high, saturating and super-saturating irradiances, the relationship becomes non-linear and ETR may either over- or underestimate gross $\mathrm{O}_{2}$ evolution (Geel et al. 1997, Franklin \& Badger 2001, Carr \& Björk 2003, Figueroa et al. 2003, Beer \& Axelsson 2004). Overestimation of gross $\mathrm{O}_{2}$ evolution by PAM (decreased $\mathrm{O}_{2}$ /ETR ratio) occurs at high irradiances in planktonic algae (Geel et al. 1997, Flameling \& Kromkamp 1998) and thin-leaved macroalgae (Hanelt \& Nultsch 1995, Franklin \& Badger 2001, Longstaff et al. 2002, Figueroa et al. 2003). This discrepancy may be related to the physiology of the algae and can be ascribed to lightdependent, $\mathrm{O}_{2}$-consuming alternative electron pathways such as photoprotective cyclic electron flow around PSII (Prasil et al. 1996, Lavaud et al. 2002), the Mehler reaction $\left(\mathrm{O}_{2}\right.$ reduction at PSI) (Schreiber et al. 1995), as well as photorespiration and chlororespiration (Beardall et al. 2003). In addition, light-enhanced dark respiration may result in increased mitochondrial $\mathrm{O}_{2}$ consumption at high irradiances (Reddy et al. 1991, Beardall et al. 1994, Ekelund 2000, Padmasree et al. 2002, Lis \& Attaia 2004). The amount of alternative electron transfer is species specific and may account for up to about half of the photosynthetic electron transport in planktonic algae (Gilbert et al. 2000, Wagner et al. 2006). In contrast, gross $\mathrm{O}_{2}$ evolution may be underestimated by ETR recordings (increased $\mathrm{O}_{2} /$ ETR ratio) in macroalgae at super-saturating irradiances (Beer \& Axelsson 2004). From our previous results (Nielsen \& Nielsen 2005), there are indications that the observed underestimation of gross $\mathrm{O}_{2}$ evolution by ETR in Fucus serratus may be due to physical reasons. The relatively thick thallus $(\sim 0.6 \mathrm{~mm})$ in combination with methodical differences between measurements of gross $\mathrm{O}_{2}$ evolution and PAM recordings may lead to the observed discrepancy (Nielsen \& Nielsen 2005).

While PAM measurements may primarily detect fluorescence emission from the outermost cell layers of the tissue (Peterson et al. 2001), measurements of $\mathrm{O}_{2}$ evolution by a Clark-type $\mathrm{O}_{2}$ electrode normally express the integrated photosynthetic response of the entire specimen. At low, sub-saturating irradiances, where the correlation between ETR and $\mathrm{O}_{2}$ evolution is good, penetration of photosynthetic active radiation (PAR) into the thallus may be restricted to the outermost cell layers that are within the PAM detecting range. As the irradiance increases, photodamage may occur and result in decreased ETR in the outermost cell layers. Simultaneous penetration of PAR deeper into the thallus, due to higher irradiance and possibly amplified by chlorophyll degradation in the surface cell layers, may induce photosynthesis in tissue beyond the PAM-detecting range. Increasing photosynthesis in the inner tissue may compensate for photodamage in the outermost cells, and, as a result, the overall photosynthetic fitness of the algae expressed by $\mathrm{O}_{2}$ evolution is maintained.

The present study sets out to evaluate the reliability of PAM-based ETR as a measure of photosynthesis in macroalgae of different thicknesses. The patterns of the light response of $\mathrm{O}_{2}$ evolution and ETR measured with conventional and imaging PAM in algae with a thin thallus (Ulva lactuca L.) and with a thick thallus (Fucus serratus L.) were studied. Imaging PAM instruments are becoming increasingly available and offer a number of advantages over conventional PAM instruments, especially the capacity to give an image of the various fluorescence parameters over a large area. This illustrates variation or enables the averaging over large areas. On the other hand, they use a different technology than conventional PAM, making direct comparisons of results doubtful. To study the effect of thallus thickness on the patterns of $\mathrm{O}_{2}$ evolution and ETR, the light responses from 'artificial thalli' of varying thicknesses were also recorded. The thickness of the 'artificial thallus' was controlled by layering tissue of Enteromorpha intestinalis (L.), a 1 cell-layer thick macroalgae.

\section{MATERIALS AND METHODS}

Algae. The sheet-like Ulva lactuca (L.) and Enteromorpha intestinalis (L.) that have the respective thallus thicknesses of 2 layers and 1 layer of small, identical cells (Lee 1999, Køie et al. 2000) represented 'thinleaved' macroalgae. Fucus serratus (L.) has a relatively complex thallus structure that comprises several layers of photosynthesizing cells represented by the medulla (the sponge-like core of the frond) and the meristoderm (the outermost palisade-like cell layers) (Lee 1999) and was chosen as a representative of 'thickleaved' macroalgae. Experimental algae were collected from local, Danish beaches in Roskilde Fjord (U. lactuca and E. intestinalis) and near Hundested on the north coast of Zealand ( $F$. serratus) and transported to the laboratory at ambient temperature $\left(15\right.$ to $\left.20^{\circ} \mathrm{C}\right)$, submerged in local seawater, within $1 \mathrm{~h} 30 \mathrm{~min}$. 
The algae were maintained at $15^{\circ} \mathrm{C}$ in aerated, local, untreated seawater at a light intensity of $250 \mu \mathrm{mol} \mathrm{m} \mathrm{m}^{-2}$ $\mathrm{s}^{-1}$ PAR that was provided by mercury lamps on a $16 \mathrm{~h}$ light/8 h dark cycle. Algae were used in experiments within $4 \mathrm{~d}$.

The light response of $\mathrm{O}_{2}$ evolution measured with a Clark-type $\mathrm{O}_{2}$ electrode and ETR calculated from fluorescence parameters acquired with 2 different PAM fluorometers, the IMAGING-PAM (Walz) and the conventional FMS-1 PAM (Hansatech Instruments) were determined for all experimental algae. The design and operating principles of the 2 PAM instruments are quite different. The imaging PAM uses an array of light-emitting diodes (LEDs) as a light source and a CCD camera for recording the fluorescence signal. This allows the measurement of fluorescence parameters over large areas (several $\mathrm{cm}^{2}$ ), as well as the recording of images of spatiotemporal variation in these parameters, but the use of LEDs limits the maximum attainable irradiance of the actinic light, as well as that of the saturating pulse. Dark adaptation using far-red light is not a built-in feature. The FMS-1 PAM is a conventional PAM design, consisting of a box containing light sources and detection electronics, and a leaf-clip connected to the box by fibre optics. The FMS-1 can provide much stronger irradiances than the imaging PAM, both as actinic light and saturating pulses, but measures only individual fluorescence parameters within the small area of the fibre optics. During these measurements, actinic light, as well as saturating pulse, intensity was set equal for the 2 types of PAM to avoid effects of different irradiances and intensities of the saturating pulse and the actinic light. Although the 2 PAM systems employ quite different detection technology (CCD camera vs. LED detector), both systems are fitted with optical filters that minimize differences in the spectral detector sensitivity (Oliver Meyerhoff, Walz \& Richard Poole, Hansatech, pers. comm.), and so the differences in detector technology will not influence recorded data for any practical purposes.

Imaging PAM. To measure imaging fluorescence values, the alga was dark adapted for $30 \mathrm{~min}$ and placed at the water-air interface in a Petri dish containing natural filtered and UV-treated seawater (seawater) at $15^{\circ} \mathrm{C}$. Focusing the transmission image of the thallus recorded on a CCD camera (IMAG-K, Walz) ensured a fixed camera working distance. An image of minimum fluorescence of the dark-adapted state $\left(F_{\mathrm{o}}\right)$ was recorded on the CCD camera and followed by an excitation pulse (intensity $2400 \mu \mathrm{mol} \mathrm{m} \mathrm{m}^{-2} \mathrm{~s}^{-1}$ and duration $0.8 \mathrm{~s}$, provided by a $470 \mathrm{~nm}$ LED ring array (IMAG-L, Walz), to yield maximum fluorescence of the dark-adapted state $\left(F_{\mathrm{m}}\right)$ and simultaneous recording of a fluorescence image. Subsequently, the alga were exposed to 8 intensities of $470 \mathrm{~nm}$ actinic light increasing from 0 to $1200 \mu \mathrm{mol} \mathrm{m} \mathrm{m}^{-2} \mathrm{~s}^{-1}$, provided by the LED ring array. Each irradiance period was $60 \mathrm{~s}$ to ensure the minimum (steady-state) fluorescence in actinic light $\left(F_{\mathrm{t}}\right)$ and was followed by an excitation pulse to yield the maximum fluorescence in actinic light $\left(F_{\mathrm{m}}{ }^{\prime}\right)$. Digital images of chlorophyll fluorescence were recorded immediately before and during each saturating pulse. Each recording was completed within 9 min. Numerical values of the chlorophyll fluorescence parameters $\left(F_{\mathrm{o}}, F_{\mathrm{m}}, F_{\mathrm{t}}\right.$ and $\left.F_{\mathrm{m}}{ }^{\prime}\right)$ were extracted from the digital images using analytical software (IMAGINGWIN, Walz). Tissue was allowed to recover in the dark, under the storage conditions described above before further analysis.

Conventional PAM. To measure fluorescence values using conventional PAM, the alga was placed in a dark-adaptation leaf-clip system at a fixed working distance from the FMS-1 measuring fibre optics (Hansatech Instruments) at an ambient temperature of $15^{\circ} \mathrm{C}$. Dark adaptation was obtained by application of a $5.5 \mathrm{~s}$ far-red $735 \mathrm{~nm}$ light pulse at $6 \mu \mathrm{mol} \mathrm{m}{ }^{-2} \mathrm{~s}^{-1}$, which ensured the full relaxation of PSII. $F_{0}$ was measured and immediately followed by a saturating light pulse provided by a broad spectrum halogen lamp (at the same intensity and duration as for imaging measurements) and simultaneous measurement of $F_{\mathrm{m}}$. Subsequently, the actinic light provided by the halogen lamp was switched on, and the light level gradually increased from 0 to $1200 \mu \mathrm{mol} \mathrm{m} \mathrm{m}^{-2} \mathrm{~s}^{-1}$. Each step lasted $60 \mathrm{~s}$, after which $F_{\mathrm{t}}$ was measured and followed by a $0.8 \mathrm{~s}$ excitation light pulse and simultaneous measurement of $F_{\mathrm{m}}{ }^{\prime}$. Each recording was completed within 9 min.

The maximum efficiency of dark-adapted PSII $\left(F_{\mathrm{v}} / F_{\mathrm{m}}\right)$ was calculated as:

$$
F_{\mathrm{v}} / F_{\mathrm{m}}=F_{\mathrm{m}}-F_{\mathrm{o}} / F_{\mathrm{m}}
$$

The maximum efficiency of PSII in actinic light (ФPSII) was calculated as:

$$
\text { ФPSII }=\left(F_{\mathrm{m}}^{\prime}-F_{\mathrm{t}}\right) / F_{\mathrm{m}}{ }^{\prime}
$$

Photosynthetic ETR ( $\mu \mathrm{mol} \mathrm{m} \mathrm{m}^{-2} \mathrm{~s}^{-1}$ ) was calculated as:

ETR $\left(\mu \mathrm{mol}\right.$ electrons $\left.\mathrm{m}^{-2} \mathrm{~s}^{-1}\right)=$

$\Phi P S I I \times$ incident PAR $\left(\mu \mathrm{mol}\right.$ photons $\left.\mathrm{m}^{-2} \mathrm{~s}^{-1}\right) \times 0.5 \times a$

where 0.5 is a correction factor based on the general assumption that half of the absorbed light energy was diverted to PSII and $a$ is the proportion of $470 \mathrm{~nm}$ PAR (imaging PAM) and broadband PAR (conventional PAM) that was absorbed by each of the replicate thalli employed in the fluorescence measurements (White \& Critchley 1999, Maxwell \& Johnson 2000). Calculation of a was based on values of light transmission through algal tissue (Table 1). Light transmission was mea- 
Table 1. The absorption coefficient $a$ used in the calculation of electron transport rates for the algae studied. Calculation of absorption coefficients was based on values of transmission of $470 \mathrm{~nm}$ photosynthetically active radiation (PAR) (imaging PAM) or broadband PAR (conventional PAM) through algal tissue and corrected for reflection. Values represent means \pm $\mathrm{SE}, \mathrm{n}=3$

\begin{tabular}{|c|c|c|}
\hline \multirow[t]{2}{*}{ Alga } & \multicolumn{2}{|c|}{ Absorption coefficient } \\
\hline & $\begin{array}{l}\text { Imaging } \\
\text { PAM }\end{array}$ & $\begin{array}{l}\text { Conventional } \\
\text { PAM }\end{array}$ \\
\hline Fucus serratus, 1 layer & $0.97 \pm 0.00$ & $0.85 \pm 0.00$ \\
\hline Ulva lactuca, 1 layer & $0.74 \pm 0.02$ & $0.62 \pm 0.02$ \\
\hline $\begin{array}{l}\text { Enteromorpha intestinalis, } \\
1 \text { layer }\end{array}$ & $0.45 \pm 0.03$ & $0.36 \pm 0.02$ \\
\hline E. intestinalis, 2 layers & $0.73 \pm 0.12$ & $0.46 \pm 0.10$ \\
\hline E. intestinalis, 4 layers & $0.92 \pm 0.02$ & $0.80 \pm 0.02$ \\
\hline E. intestinalis, 6 layers & $0.97 \pm 0.01$ & $0.96 \pm 0.00$ \\
\hline E. intestinalis, 8 layers & $0.98 \pm 0.00$ & $0.90 \pm 0.01$ \\
\hline
\end{tabular}

sured by the opal glass technique (Shibata 1959) in a Shimadzu 1600 spectrophotometer. Absorption values measured in this way were corrected for reflected light, measured with a Konica Minolta CM-2600 handheld spectrophotometer using an integrating sphere to ensure that values of $a$ are true absorption values without any contribution from reflection.

$\mathbf{O}_{2}$ evolution. Photosynthesis was measured following dark adaptation of the same algal material as used in the PAM measurements as continuous $\mathrm{O}_{2}$ evolution from algae in a closed system fitted with a Clark-type $\mathrm{O}_{2}$ electrode (S1 Oxygen Electrode Disc, Hansatech Instruments). The voltage across the electrode was calibrated to $\mathrm{O}_{2}$-depleted and $\mathrm{O}_{2}$-saturated seawater (equilibrium with atmospheric air). Dark-adapted algal material (approximately $2 \mathrm{~cm}^{2}$ ) was submerged in $15 \mathrm{ml}$ of seawater in the electrode chamber (D3, Hansatech Instruments) that was temperature adjusted to $15^{\circ} \mathrm{C}$ with a circulating water jacket and stirred with a Hansatech magnetic follower and stirrer unit to reduce boundary layer effects. The alga was held in place perpendicular to the direction of light inside the chamber by means of placing a piece of mesh inside the chamber on the shaded side of the algal piece. Oxygen evolution was measured at 8 incident light intensities increasing from 0 to $1200 \mu \mathrm{mol} \mathrm{m} \mathrm{m}^{-2} \mathrm{~s}^{-1}$ white light provided by a tungsten halogen light source. To ensure stable measuring conditions and steady-state photosynthesis, the system was allowed to stabilise for 1 min between recordings and each light response curve was completed within $12 \mathrm{~min}$. Measurements of thallus areas were achieved by scanning the algal pieces into SigmaScan Pro (SPSS Inc.) and calculating the area according to a calibration of pixel numbers per area unit. Net $\mathrm{O}_{2}$ evolution $\left(\mu \mathrm{mol} \mathrm{O} \mathrm{O}_{2} \mathrm{~m}^{-2} \mathrm{~s}^{-1}\right)$ was calculated as:
Net $\mathrm{O}_{2}$ evolution, $P=(C \times \Delta U \times V) /(U \times A)$

where $C$ is the $\mathrm{O}_{2}$ concentration $\left(\mu \mathrm{mol} \mathrm{l^{-1 }}\right)$ of $\mathrm{O}_{2}$-saturated seawater at $15^{\circ} \mathrm{C}$ (Green \& Carritt 1967), $U$ is the charge across the electrode at $\mathrm{O}_{2}$ saturation $(\mathrm{mV}), \Delta U$ is the change in voltage across the electrode over time $\left(\mathrm{mV} \mathrm{s}^{-1}\right), V$ is the volume of the incubation medium (l) and $A$ is the area of the frond $\left(\mathrm{m}^{-2}\right)$. Gross $\mathrm{O}_{2}$ evolution $(P)$ was calculated as net $\mathrm{O}_{2}$ evolution plus darkadapted dark respiration.

Effects of thallus thickness. Measurements of photosynthesis and fluorescence parameters were carried out on single layers of a thin (Ulva lactuca) and thick (Fucus serratus) macroalgae. To determine the effect of tissue thickness on the light response of photosynthesis, as well as conventional and imaging fluorescence parameters, measurements were also carried out on 'artificial thalli' that were 1, 2, 4, 6 and 8 cell layers thick. Artificial thalli were built from layers of Enteromorpha intestinalis that, due to the uniform thickness of the thallus and the distribution of chloroplasts, were assumed to have a chlorophyll a concentration per unit area that related linearly to the cell layers of the artificial thallus. Replicate recordings were performed of 7 individual algal pieces of each of the 2 macroalgae $(k=2, \mathrm{n}=7)$ and each of the 5 thallus thicknesses of the artificial thalli $(k=5, \mathrm{n}=7)$. To verify that $\mathrm{O}_{2}$ accumulation and $\mathrm{CO}_{2}$ deficiency in F. serratus and the artificial thallus would be negligible and irrelevant for fluorescence recordings, gas diffusion out of thick algal tissue was measured as $\mathrm{O}_{2}$ diffusion with an $\mathrm{O}_{2}$ microelectrode inserted in the algal tissue (Nielsen, Nielsen \& Pedersen unpubl. data).

Chlorophyll a content. For measurements of chlorophyll $a$, the algal samples were lyophilized and ground to a fine powder, which was extracted with $96 \%$ ethanol. Chlorophyll was measured spectrophometrically according to Wintermans \& DeMots (1965).

Data treatment, general considerations. While $\mathrm{O}_{2}$ evolution and ETR are sometimes measured simultaneously, the approach was not suitable for the present experiment. The fluorescence emission from thin thalli was very low and became attenuated further, and values became unreliable when measured with the conventional FMS-1 measuring fibre-optics through the water jacket and glass walls of the Hansatech D3 electrode chamber, although designed to be used together by the manufacturer. Serial measurements of $\mathrm{O}_{2}$ evolution and conventional ETR provided higher fluorescence values and more reliable results. Similarly, the imaging PAM, due to its general design and lay-out, was unsuitable for performing measurements of ETR simultaneously with $\mathrm{O}_{2}$ evolution.

The algae in this study have been found to have different chloroplast displacement reactions in response 
to light (Nultsch \& Pfau 1979, Britz \& Briggs 1987, Hanelt et al. 2003). However, the chloroplast movements of the algae in the present study have no effect on either photosynthetic activity or chlorophyll fluorescence parameters (Nultsch et al. 1981, Brugnoli \& Björkman 1992, Hanelt et al. 2003). Furthermore, chloroplast movement is a relatively slow process (on the order of hours; Hanelt et al. 2003, Williams et al. 2003); thus, downregulation of photosynthesis will take place by dynamic photoinhibition before any effect of chloroplast movement can be detected (Hanelt \& Nultsch 1991). We therefore conclude that differences in chloroplast movements would be irrelevant in the short-term experiments of the present study.

It could be argued that due to the different absorption characteristics of the various algal thalli and due to the different emission spectra of the lamps employed in the various experiments, a spectral correction to express chlorophyll fluorescence and photosynthesis parameters on the basis of absorbed rather than emitted light is necessary. When we did a spectral correction, we found only minor differences between data expressed on the basis of emitted light and data expressed on the basis of absorbed light, and none that would change the conclusions drawn. Expressing data on the basis of absorbed rather than emitted light would make statistical analysis of the data very complex, since data points would not have common $x$-values. We have therefore chosen to express data on the basis of emitted light throughout the manuscript.

Statistical analysis. Statistical analysis was carried out according to Quinn \& Keough (2002) using MINITAB 15. Before parametric testing, the data were tested for homogeneity of variance (Cochran's test) and normal distribution. Normalized data were arcsine transformed before analysis. Data were subjected to 1and 2-way analysis of variance. Differences between individual means were tested further by post hoc multiple range tests (Tukey test) from which information about photosynthetic light saturation and photoinhibition was extracted. All tests were carried out at a level of significance of $\mathrm{p}<0.05$, and errors are displayed graphically as \pm 1 standard error (SE).

\section{RESULTS}

\section{Correlation between $P$ and ETR measured by conventional and imaging PAM}

At sub-saturating irradiances the light response of $\mathrm{O}_{2}$ evolution was related to that of imaging ETR in both thin-leaved (Fig. 1a) and thick-leaved algae (Fig. 1b). There was no significant difference between the initial slope (0 to $150 \mu \mathrm{mol} \mathrm{m} \mathrm{m}^{-2} \mathrm{~s}^{-1} \mathrm{PAR}$ ) of the light response of
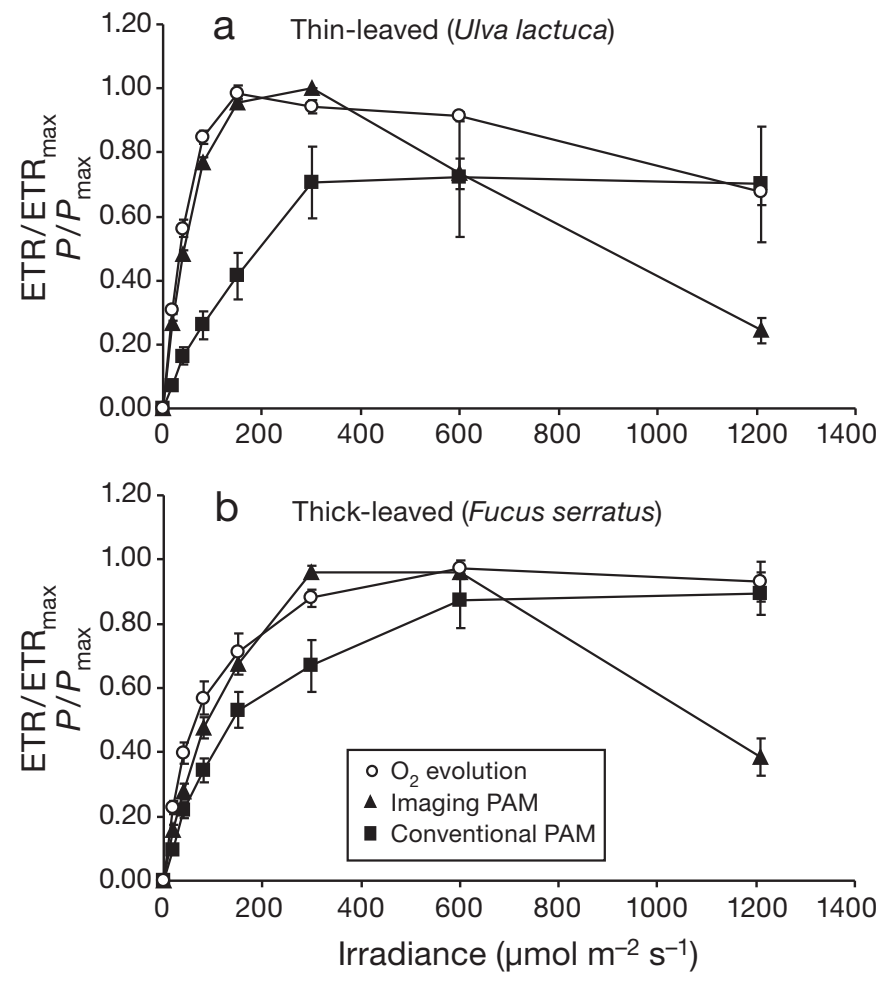

Fig. 1. Light response of ETR and $\mathrm{O}_{2}$ evolution $(P)$ in: (a) Ulva lactuca and (b) Fucus serratus. ETR was normalised to ETR $\max$ and was $P$ normalised to $P_{\max }$ for each replicate frond. Values represent means $\pm 1 \mathrm{SE}, \mathrm{n}=7$

$P / P_{\max }$ ( $P$ relative to $P_{\max }$ ) and that of the light response of imaging $E T R / E T R_{\max }\left(E T R\right.$ relative to $E R_{\max }$ ) in either thin- or thick-leaved algae. In both species $P / P_{\max }$ and imaging ETR/ETR ${ }_{\max }$ became light saturated at the same irradiance: $150 \mu \mathrm{mol} \mathrm{m} \mathrm{m}^{-2} \mathrm{~s}^{-1}$ in Ulva lactuca and $300 \mu \mathrm{mol} \mathrm{m} \mathrm{m}^{-2} \mathrm{~s}^{-1}$ in Fucus serratus. While the light-response pattern of $P$ was related to that of imaging ETR, imaging ETR had a non-significant tendency to underestimate $P$ at sub-saturating and saturating irradiances. The $\mathrm{O}_{2}$ /imaging ETR ratio was in the region of 0.3 to 0.5 for both species (Fig. 2) and calculations of $\mathrm{O}_{2}$ evolution based on imaging PAM results at sub-saturating irradiances would require multiplication of ETR with correction factors of 1.2 to 1.7 for F. serratus and of 1.8 to 2.0 for U. lactuca. In contrast to the lightresponse pattern of imaging ETR, sub-saturated $\mathrm{O}_{2}$ evolution was unrelated to ETR measured by conventional PAM (Fig. 1). The initial slope of the light response of conventional ETR/ETR $\mathrm{Eax}_{\text {ax }}$ wasnificantly lower than that of $P / P_{\max }$ for both thin $(\mathrm{p}<0.001)$ and thick ( $p=0.018$ ) macroalgae, and conventional ETR became light saturated at higher irradiances than $\mathrm{O}_{2}$ evolution in both species: $300 \mu \mathrm{mol} \mathrm{m}^{-2} \mathrm{~s}^{-1}$ in U. lactuca and $600 \mu \mathrm{mol} \mathrm{m} \mathrm{m}^{-2} \mathrm{~s}^{-1}$ in F. serratus. While there was a discrepancy between the light-response patterns of 


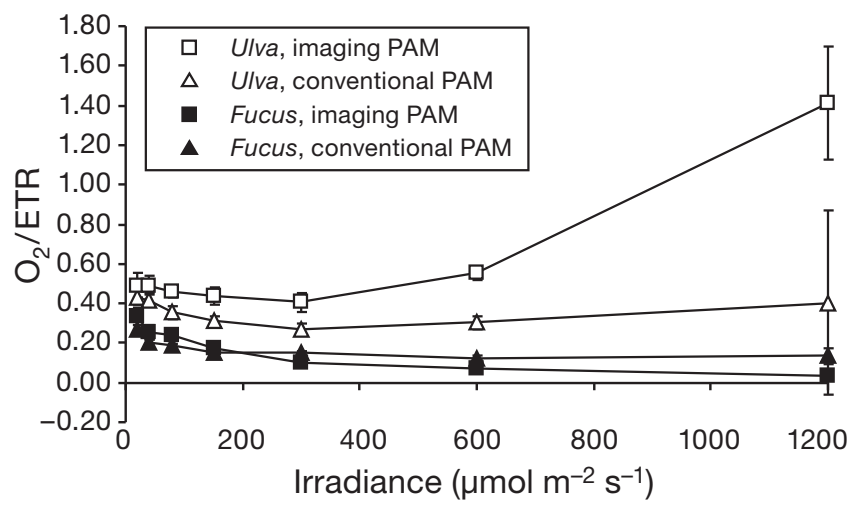

Fig. 2. Imaging and conventional $\mathrm{O}_{2}$ /ETR ratios for Ulva lactuca and Fucus serratus as a function of irradiances. Values represent means $\pm 1 \mathrm{SE}, \mathrm{n}=7$

$P$ and conventional ETR at sub-saturating and saturating irradiances, theoretical calculations of $P$ could be based on conventional ETR at very low irradiances, as the conventional $\mathrm{O}_{2} /$ ETR ratio was close to 0.25 at irradiances $<80 \mu \mathrm{mol} \mathrm{m}{ }^{-2} \mathrm{~s}^{-1}$ (Fig. 2). At irradiances $>80 \mathrm{umol} \mathrm{m}^{-2} \mathrm{~s}^{-1}$ conventional $\mathrm{O}_{2} /$ ETR ratios decreased below 0.25 and had a tendency to overestimate $P$.

At super-saturating irradiances the correlation between $P / P_{\max }$ and imaging ETR/ETR $\mathrm{max}_{\max }$ broke down, and $P / P_{\max }$ became correlated with conventional ETR/ $\mathrm{ETR}_{\max }$ in both algae. There were differences in the light response of $P$ and imaging ETR between the 2 algae that were expressed by a significant species $\times$ light interaction $(p<0.001)$ for both parameters. In thin-leaved algae, photoinhibition was expressed by imaging ETR/ETR ${ }_{\max }$ and $P / P_{\max }$ (Fig. 1a). There was a significant $16 \%$ decrease in imaging ETR as the irradiance increased from 300 to $600 \mu \mathrm{mol} \mathrm{m}^{-2} \mathrm{~s}^{-1}$ PAR $(\mathrm{p}=0.010)$. Further decrease in imaging ETR (75\%) was accompanied by a $35 \%$ reduction in $P(\mathrm{p}=0.026)$ as the irradiance increased to $1200 \mathrm{~mol} \mathrm{~m}^{-2} \mathrm{~s}^{-1}$ PAR (Fig. 1a). In contrast, there was no significant effect on conventional ETR/ETR $\mathrm{max}_{\max }$ as the irradiance increased from 300 to $1200 \mu \mathrm{mol} \mathrm{m}^{-2} \mathrm{~s}^{-1}$ in thin-leaved algae. In thick-leaved algae, photoinhibition was expressed only by imaging ETR and not conventional ETR and $P$. Imaging ETR decreased by two-thirds ( $\mathrm{p}<0.001$ ), whereas conventional ETR and $P$ continued at the maximum rate as the irradiance increased from 600 to $1200 \mu \mathrm{mol} \mathrm{m}^{-2} \mathrm{~s}^{-1}$, which was the highest experimental irradiance (Fig. 1b).

\section{Effect of thallus thickness on $P$ and ETR measured by conventional and imaging PAM}

In artificial thalli that were 1 to 8 cell layers thick there was significant thickness $\times$ light interaction for
$P / P_{\max }(\mathrm{p}<0.001)$, as well as for imaging ETR/ETR $\mathrm{max}_{\max }$ $(p=0.002)$. When thalli that were 1 and 2 cell layers thick (thin artificial thalli) were compared, there were no significant differences in either $P / P_{\max }$ or in imaging

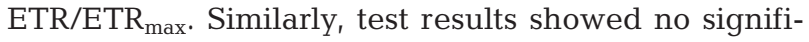
cant differences in $P / P_{\max }$ or in imaging ETR/ETR $R_{\max }$ when thick artificial thalli (4 to 8 cell layers) were compared. The light responses of both $P / P_{\max }$ and imaging ETR/ETR $\mathrm{Exx}_{\max }$ in thin artificial thalli that were 1 and 2 cell layers thick were different compared with those of thick thalli that were 4,6 and 8 cell layers thick (Fig. 3a,b). In contrast to $P / P_{\max }$ and imaging ETR/ ETR $_{\max }$, there was no significant effect of thallus thick-

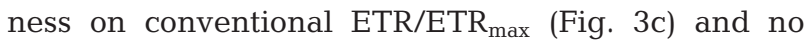
difference in conventional ETR/ETR $\max$ between Ulva lactuca, Fucus serratus and artificial thallus.
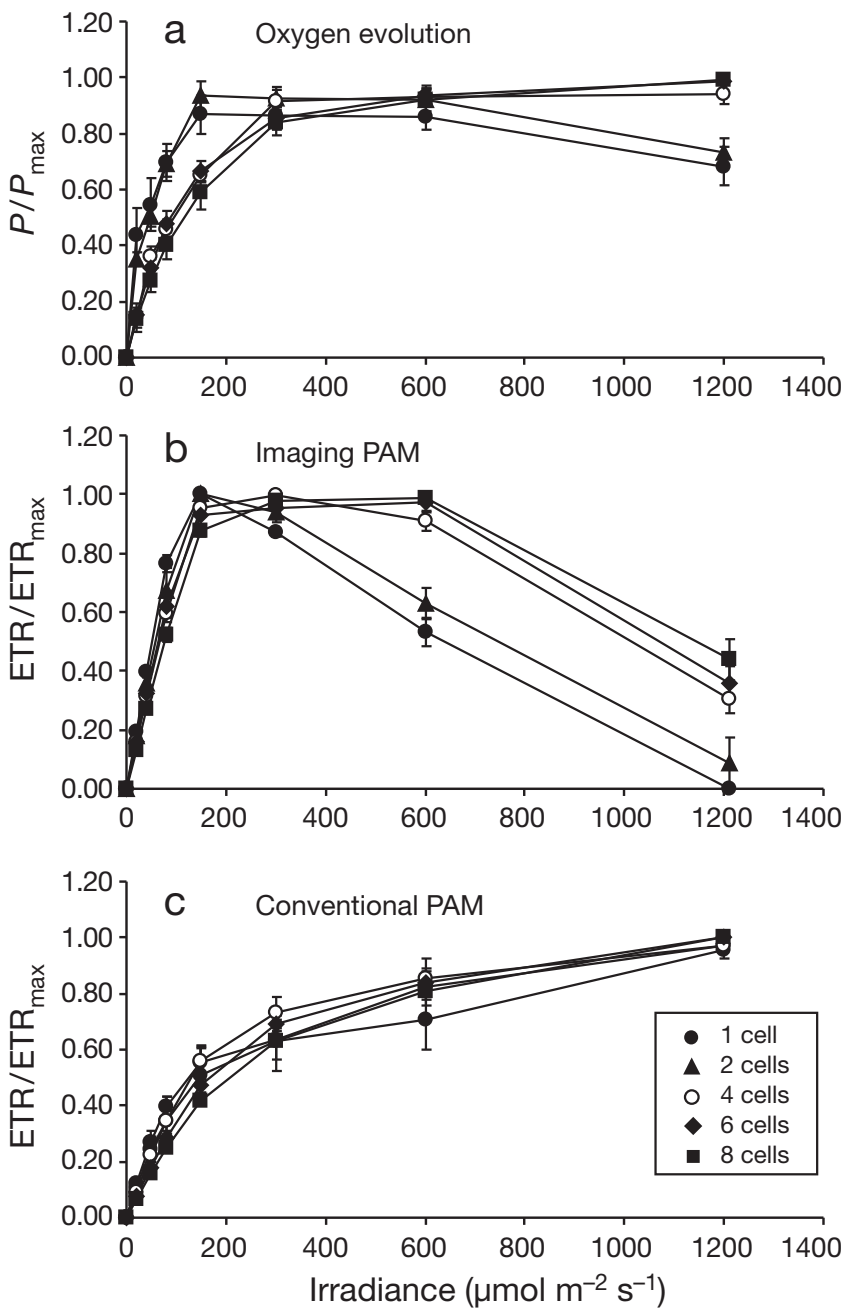

Fig. 3. Light response in artificial thallus (built from layers of Enteromorpha intestinalis) that was 1 to 8 cell layers thick: (a) $P$ normalised to $P_{\max }$, (b) imaging ETR normalised to imaging $\mathrm{ETR}_{\max }$ and (c) conventional ETR normalised to conventional ETR $_{\max }$. Values represent means $\pm 1 \mathrm{SE}, \mathrm{n}=7$ 
In thin-leaved algae the light responses of $P / P_{\max }$ and

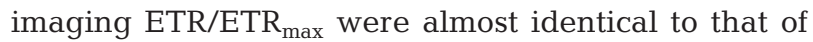
thin artificial thalli (1 to 2 cell layers) (Figs. 1a \& 4a). There were no significant algae $\times$ light interactions for either $P / P_{\max }$ or imaging ETR/ETR $\max$ when thin artificial thallus and Ulva lactuca were compared. Similar to $U$. lactuca, in thin artificial thalli there was no difference in the initial slope of the $P / P_{\max }$ and imaging ETR/ ETR $_{\text {max }}$ light response, both of which became light saturated at $150 \mu \mathrm{mol} \mathrm{m} \mathrm{m}^{-2} \mathrm{~s}^{-1} \mathrm{PAR}$. In contrast, the initial slope of the conventional ETR/ETR $\mathrm{Eax}_{\max }$ light response was significantly lower than that of $P / P_{\max }(\mathrm{p}=0.005)$.

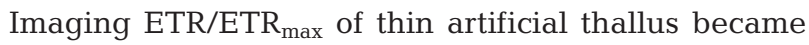
photoinhibited at $300 \mu \mathrm{mol} \mathrm{m} \mathrm{m}^{-2} \mathrm{~s}^{-1}$, which was lower than in U. lactuca. Similar to the response of U. lactuca, $P / P_{\max }$ of thin artificial thallus became photoinhibited at $1200 \mu \mathrm{mol} \mathrm{m} \mathrm{m}^{-2} \mathrm{~s}^{-1}$ and the imaging $\mathrm{O}_{2} /$ ETR ratio increased significantly (Fig. 5).

In thick-leaved algae the light responses of $P / P_{\max }$ were identical to those of thick artificial thalli (4 to 8 cell layers) (Figs. 1b \& 4b). There were no significant algae $\times$ light interactions for $P / P_{\max }$ when thick artificial thallus and Fucus serratus were compared and no significant difference in the initial slope of the $P / P_{\max }$
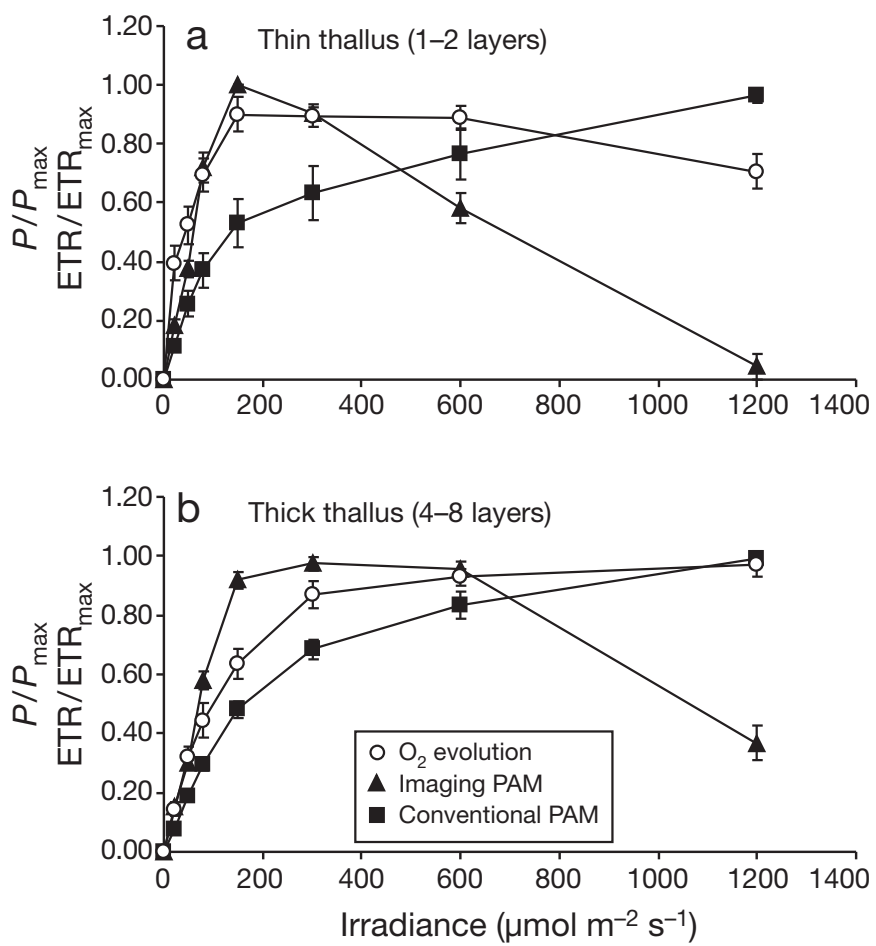

Fig. 4. Light response of $\mathrm{O}_{2}$ evolution $(P)$, imaging ETR and conventional ETR in: (a) thin artificial thallus (1 to 2 cell layers) and (b) thick artificial thallus (4 to 8 cell layers): $P$ was normalised to $P_{\max }$, imaging ETR was normalised to imaging ETR $_{\max }$ and conventional ETR was normalised to conventional $\mathrm{ETR}_{\max }$. Values represents means $\pm 1 \mathrm{SE}, \mathrm{n}=7$

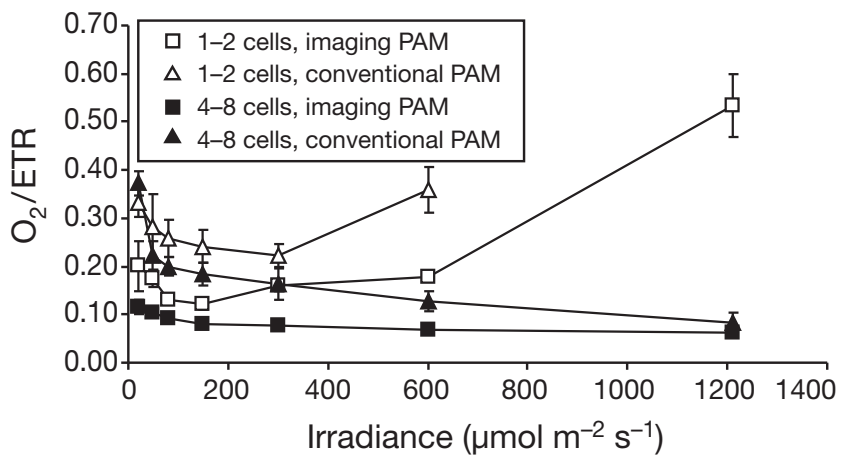

Fig. 5. Imaging and conventional $\mathrm{O}_{2}$ /ETR ratios for thin artificial thallus ( 1 to 2 cell layers) and thick artificial thallus (4 to 8 cell layers) as a function of irradiances. Values represent means $\pm 1 \mathrm{SE}, \mathrm{n}=7$

light response of thick artificial thalli and that of $F$. serratus. Similar to F. serratus, $P / P_{\max }$ became light saturated at $300 \mu \mathrm{mol} \mathrm{m} \mathrm{m}^{-2} \mathrm{~s}^{-1}$ and remained at the maximum level as the irradiance increased to $1200 \mu \mathrm{mol}$ $\mathrm{m}^{-2} \mathrm{~s}^{-1}$. In contrast, tests showed that there were significant tissue $\times$ light interactions between the imaging

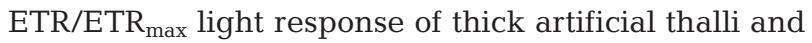
both Ulva lactuca and F. serratus ( $p<0.001)$. However,

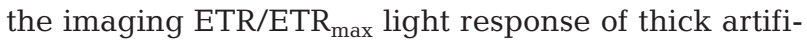
cial thalli was similar to that of thin-leaved algae at sub-saturating irradiances and similar to that of thickleaved algae at saturating and super-saturating irradiances (Fig. 4b). While the initial slope of the imaging

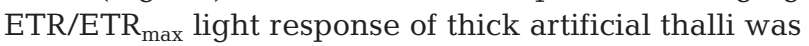
significantly different from that of $F$. serratus $(\mathrm{p}=$ 0.006), there was no difference in the initial slope

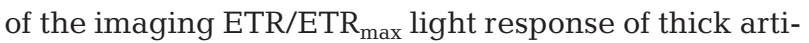
ficial thallus and that of U. lactuca. Similar to U. lac-

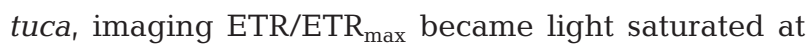
$150 \mu \mathrm{mol} \mathrm{m} \mathrm{m}^{-2} \mathrm{~s}^{-1}$.

In contrast to Ulva lactuca and similar to Fucus serra-

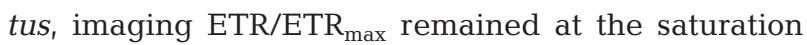
level as the irradiance increased to $600 \mu \mathrm{mol} \mathrm{m} \mathrm{m}^{-2} \mathrm{~s}^{-1}$ and only expressed photoinhibition at $1200 \mu \mathrm{mol} \mathrm{m} \mathrm{m}^{-2}$ $\mathrm{s}^{-1}$ in thick artificial thallus. In contrast to thin- and thick-leaved algae and thin artificial thallus at subsaturating irradiances, the initial slope of $P / P_{\max }$ was unrelated to that of imaging ETR/ETR $\mathrm{Eax}_{\max }$ in thick artificial thallus $(\mathrm{p}<0.001)$.

\section{Effects of tissue thickness on fluorescence data}

There was a significant linear increase in both $F_{\mathrm{m}}$ and $F_{\mathrm{o}}$ measured with conventional PAM as the thickness of artificial thallus increased from 1 to 8 cell layers (Fig. 6a; $\mathrm{p}<0.001$ ), which was equivalent to a similar increase in the chlorophyll a concentration per unit 

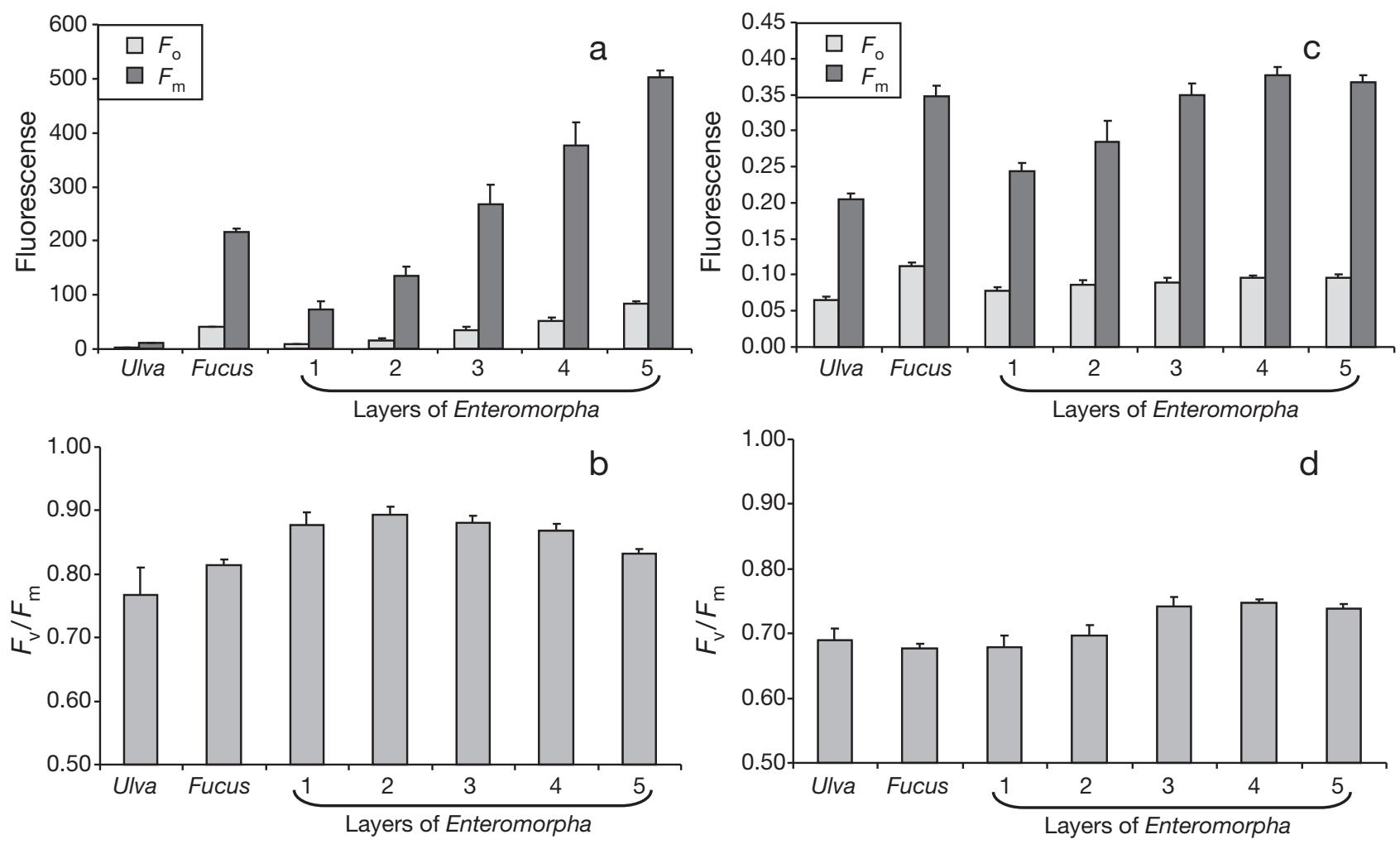

Fig. 6. (a) Conventional $F_{\mathrm{o}}$ and $F_{\mathrm{m}}$ (b) conventional $F_{\mathrm{v}} / F_{\mathrm{m}}$ (c) imaging $F_{\mathrm{o}}$ and $F_{\mathrm{m}}$ and (d) imaging $F_{\mathrm{v}} / F_{\mathrm{m}}$. Values represent means $+1 \mathrm{SE}, \mathrm{n}=7$

area when comparing Fucus serratus to Ulva lactuca and Enteromorpha intestinalis (Fig. 7). These findings indicate that the saturating pulse of the conventional PAM was saturating throughout the tissue of both thinand thick-leaved algae. There was no effect of thallus thickness on the conventional PAM measurements of maximum quantum yield of PSII $\left(F_{\mathrm{v}} / F_{\mathrm{m}}\right)$ up to 6 cell layers (Fig. 6b).

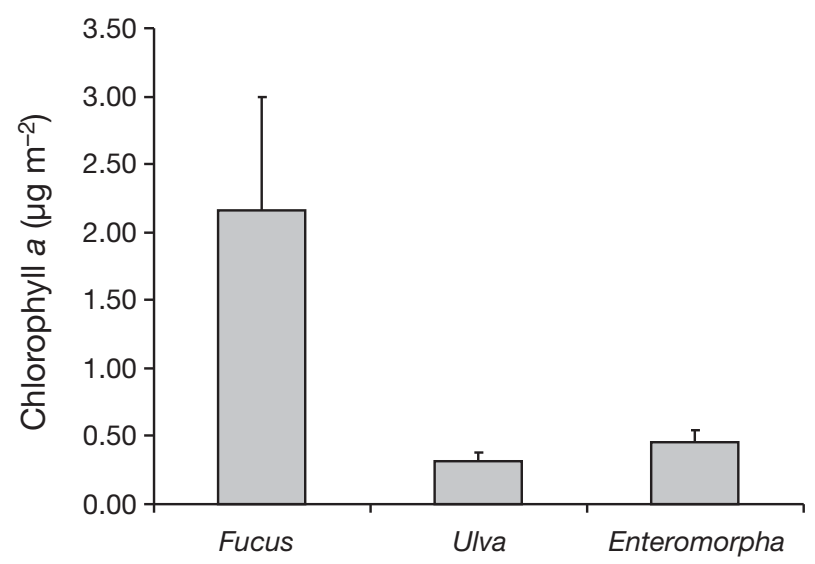

Fig. 7. Chlorophyll a content of experimental algae. Values represent means $+1 \mathrm{SE}, \mathrm{n}=7$
In contrast to the conventional PAM that detects fluorescence emission from the entire tissue, imaging PAM measurements may only acquire fluorescence data from the outermost cell layers of thick algae. Increasing the thickness of artificial thallus from 1 to 4 cells (equivalent to a 4 -fold increase in chlorophyll $a$ concentration per area unit) resulted in a significant increase in $F_{\mathrm{m}}$ (Fig. 6c; p < 0.001). Further increase in the thallus thickness from 4 to 8 cells had no significant effect on $F_{\mathrm{m}}$ although the chlorophyll a concentration per area unit was doubled. In contrast, the tendency of $F_{\mathrm{o}}$ to increase in response to increasing thallus thickness was not significant (Fig. 6c). Consequently, there was a significant increase in $F_{\mathrm{v}} / F_{\mathrm{m}}$ as thallus thickness increased from 1 to 4 cells (Fig. $6 d_{i} p=0.012$ ). In thicker thallus ( $>4$ cell layers), there was no significant effect of thallus thickness on $F_{\mathrm{v}} / F_{\mathrm{m}}$.

\section{DISCUSSION}

Results from this study show that, while ETR measured with conventional and imaging PAM may provide some indication of the photosynthetic status of macroalgae, neither of the techniques provide lightresponse patterns of ETR/ETR $R_{\max }$ that reflect that of 
$P / P_{\max }$ at all irradiance levels, i.e. sub-saturating, saturating and super-saturating irradiances.

There is generally a good correlation between ETR and $\mathrm{O}_{2}$ evolution in macroalgae at sub-saturating and saturating irradiances (Hanelt \& Nultsch 1995, Franklin \& Badger 2001, Longstaff et al. 2002, Figueroa et al. 2003). Our measurements of imaging ETR/ $\mathrm{ETR}_{\text {max }}$ provide a very accurate reflection of the lightresponse pattern of $P / P_{\max }$ at sub-saturating and saturating irradiances. At super-saturating irradiances, $\mathrm{O}_{2}$ evolution usually shows a tendency to be reduced compared to ETR (Hanelt \& Nultsch 1995, Franklin \& Badger 2001, Figueroa et al. 2003), due to physiological, photoprotective responses (Schreiber et al. 1995, Prasil et al. 1996, Lavaud et al. 2002, Beardall et al. 2003). Results of the present study show a pronounced reduction in imaging ETR/ETR max $_{\text {compared to } P / P_{\text {max }}}$ at super-saturating irradiances. We also observed a distinct differentiation between thin- and thick-leaved algae in the light responses of $\mathrm{O}_{2}$ evolution and ETR. The observed responses may be related to the physical properties of the algae, as well as to shortcomings in the imaging PAM.

There were distinctive differences in imaging ETR and $\mathrm{O}_{2}$ evolution at super-saturating irradiances between thin and thick macroalgae. In thin-leaved algae, measurements of imaging ETR and $\mathrm{O}_{2}$ evolution refer to the same tissue and the light-response patterns of these parameters are similar. The reduction in imaging ETR and $\mathrm{O}_{2}$ evolution at super-saturating irradiances is consistent with chronic photoinhibition, which may occur at super-saturating irradiances as a result of photon-induced damage to the photosynthetic apparatus (Osmond 1994). The results are in keeping with lowered ETR, measured with a Walz Diving PAM in Ulva lactuca at super-saturating irradiances between 600 and $1200 \mu \mathrm{mol} \mathrm{m} \mathrm{m}^{-2} \mathrm{~s}^{-1}$ PAR (Longstaff et al. 2002). While the imaging PAM has a limited detection range into macroalgal tissue, recordings provide information about the photosynthetic performance throughout the tissue of thin-leaved algae. In contrast, in thick-leaved algae, imaging ETR measurements may apply only to the outermost cells of the thallus and not the deeper cell layers because of the restricted detecting range of the PAM instrument.

The results show that as the thallus thickness of the algae increases, the algal morphology becomes increasingly important for the relationship between imaging ETR and $\mathrm{O}_{2}$ evolution and the overall photosynthesis of algae may overrule local physiological adaptations. In contrast to thin-leaved algae, there was a large deviation of imaging ETR/ETR $\mathrm{max}_{\text {ax }}$ from that of $P / P_{\max }$ at super-saturating irradiances in thick algae. Thick-leaved brown algae such as Fucus serratus have a relatively complex thallus structure that comprises several layers $(>10)$ of photosynthesizing cells (Lee 1999), some of which may be beyond the imaging PAM detection range. At sub-saturating irradiances, there is good correlation between the patterns of imaging ETR/ETR max $_{\text {ax }}$ and $P / P_{\max }$, possibly because photosynthesis primarily takes place in the outermost cell layers within the imaging PAM detection range due to rapid attenuation of light in the tissue (Vogelmann 1993). At super-saturating irradiances photodamage in the outermost cell layers was detected by the imaging PAM recordings in thick-leaved macroalgae. In contrast, conventional PAM and $\mathrm{O}_{2}$ evolution measurements by use of a Clark-type electrode express the performance of the entire tissue and integrate both photodamage in the outer cell layers and increased photosynthesis in deeper cells outside the imaging PAM range, as the higher irradiance penetrated deeper into the thallus.

In contrast to results of the imaging PAM, the lightresponse pattern of conventional ETR/ETR $\mathrm{max}_{\max }$ did not reflect the light-response patterns of $P / P_{\max }$ at subsaturating and saturating irradiances. However, at super-saturating irradiances conventional PAM provided the most accurate reflection of photosynthesis.

The general discrepancy between the light-response patterns of conventional ETR/ETR $R_{\max }$ and $P / P_{\max }$ at sub-saturating and saturating irradiances may be related to the physiological properties of the algae and the applied protocol for determination of gross $\mathrm{O}_{2}$ evolution. Gross $\mathrm{O}_{2}$ evolution was calculated according to common methodology as net $\mathrm{O}_{2}$ evolution plus darkadapted dark respiration without consideration for light-enhanced dark respiration (LEDR). While there are indications in the literature that light-induced inhibition of dark respiration may occur (Krömer 1995), the consensus is that high irradiances enhance mitochondrial respiration (Padmasree et al. 2002, Lis \& Attaia 2004). The stimulation of mitochondrial respiration by photosynthesis, LEDR (Reddy et al. 1991, Padmasree et al. 2002, Lis \& Attaia 2004), is known to occur in planktonic algae under saturating irradiances (Beardall et al. 1994, Ekelund 2000). Calculated gross photosynthesis may have been higher at super-saturating irradiances had LEDR been accounted for. In turn, the light-response pattern of $P / P_{\max }$ would have been more similar to that of conventional ETR/ETR max $_{\text {with a less }}$ steep initial slope at sub-saturating irradiances and a shift in light saturation levels towards higher irradiances.

While the light-response pattern of conventional ETR/ETR $_{\max }$ may have been biased towards higher irradiances compared to that of $P / P_{\max }$, there was some correlation between conventional ETR and photosynthesis at very low irradiances. Theoretically, photosynthesis could be calculated from conventional ETR at irradiances $<80 \mu \mathrm{mol} \mathrm{m} \mathrm{m}^{-2} \mathrm{~s}^{-1}$, although such calcula- 
tions would underestimate photosynthesis at higher irradiances. An $\mathrm{O}_{2}$ /ETR ratio close to 0.25 is a general response of macroalgae and phytoplankton at subsaturating irradiances (Geel et al. 1997, Figueroa et al. 2003, Carr \& Björk 2003, Beer \& Axelsson 2004). Similarly, the reduction in the conventional $\mathrm{O}_{2} /$ ETR ratio to values $<0.25$ with increasing irradiances is known in plankton and thin- and thick-leaved macroalgae and is thought to be related to physiological photoprotective factors, such as cyclic electron flow around PSII and the Mehler reaction, which would increase the electron transport relative to the $\mathrm{O}_{2}$ evolution (Prasil et al. 1996, Geel et al. 1997, Franklin \& Badger 2001).

In contrast to conventional ETR, theoretical calculations of photosynthesis could not be based on imaging ETR at any irradiance. An increased $\mathrm{O}_{2}$ /ETR ratio has been reported previously (Beer \& Axelsson 2004), and there are indications from the literature that reduced ETR relative to $\mathrm{O}_{2}$ evolution at super-saturating irradiances may be related to weaknesses in the PAM methodologies (Suggett et al. 2003).

\section{CONCLUSION}

PAM is a powerful tool for studying photosynthetic parameters in macroalgae. However, the physiological properties of the algae (Padmasree et al. 2002, Lis \& Attaia 2004) and the type of PAM instrument applied may influence the light-response pattern of ETR compared to that of photosynthesis. Especially the following points should be taken into consideration:

- The use of conventional PAM is widespread, and this type of PAM is better known than the imaging PAM type, which in itself can be construed as an advantage. The conventional PAM may provide the best estimate of actual photosynthesis; however, the imaging PAM is better suited for detecting photosynthetic lightresponse patterns (the shape of the irradiance-ETR curves) at sub-saturating and saturating irradiances.

- PAM recordings should be regarded as a compliment to measurements of photosynthesis - and not vice versa - in studies of marine macroalgal photosynthesis.

- ETR may either under- or overestimate photosynthesis, in particular at super-saturating irradiances, and chlorophyll fluorescence results should be treated with caution when extrapolated to express the physiological fitness of the entire individual.

- This is especially the case when studying photosynthetic systems with a distinct 3-dimensional structure, such as thick-leaved macroalgae and higher plants, but also sediment-associated microphytobenthic communities.

- Measurements of photosynthetic oxygen evolution will always provide the integrated systems' photo- synthesis, and should be considered the real photosynthetic values. Conventional PAMs will tend to underestimate oxygen evolution at sub-saturating and saturating irradiances, possibly due to physiological properties of the algae, while imaging PAMs tend to underestimate oxygen evolution at high, super-saturating irradiances due to physical/anatomical properties of the algae (their thickness).

- Studies where PAM recordings are employed as the only measure of the photosynthetic responses of thick-leaved marine macroalgae (Häder et al. 1998, Gévaert et al. 2003, Gómez et al. 2004, Strain et al. 2006) carry a pronounced risk that the responses of the individual algae, as well as the ecological consequences, are misinterpreted, compared to studies where PAM recordings are accompanied by measurements of oxygen evolution.

Acknowledgements. The work was supported by research grants ANS-1341/20 and ANS-04-0463/10 from The Carlsberg Foundation. H.D.N. was supported by a research grant (272-06-0206) from the Danish Natural Science Research Council.

\section{LITERATURE CITED}

Beardall J, Burgerwiersma T, Rijkeboer M, Sukenik A, Lemoalle J, Dubinsky Z, Fontvielle D (1994) Studies on enhanced post-illumination respiration in microalgae. J Plankton Res 16:1401-1410

Beardall J, Quigg A, Raven JA (2003) Oxygen consumption: photorespiration and chlororespiration. In: Larkum AW, Douglas SE, Raven JA (eds) Photosynthesis in algae. Kluwer Academic Publishers, Amsterdam, p 157-181

Beer S, Axelsson L (2004) Limitations in the use of PAM fluorometry for measuring photosynthetic rates of macroalgae at high irradiances. Eur J Phycol 39:1-7

Britz SJ, Briggs WR (1987) Chloroplast movement and light transmission in Ulva: the sieve effect in a light-scattering system. Acta Physiol Plant 9:149-162

Brugnoli E, Björkman O (1992) Chloroplast movement in leaves: influence on chlorophyll fluorescence and measurements of light-induced absorbance changes related to $\mathrm{pH}$ and zeaxanthin formation. Photosynth Res 32:23-35

Carr H, Björk M (2003) A methodological comparison of photosynthetic oxygen evolution and estimated electron transport rate in tropical Ulva (Chlorophyceae) species under different light and inorganic carbon conditions. J Phycol 39:1125-1131

Ekelund NGA (2000) Interactions between photosynthesis and 'light-enhanced dark respiration' (LEDR) in flagellate Euglena gracilis after illumination with ultraviolet radiation. J Photochem Photobiol B 55:63-69

Figueroa FL, Conde-Álvarez R, Gómez I (2003) Relation between electron transport rates determined by pulse amplitude modulated chlorophyll fluorescence and oxygen evolution in macroalgae under different light conditions. Photosynth Res 75:259-275

Flameling IA, Kromkamp J (1998) Light dependence of quantum yield for PSII charge separation and oxygen evolution in eukaryotic algae. Limnol Oceanogr 43:284-297

Franklin LA, Badger MR (2001) A comparison of photosyn- 
thetic electron transport rates in macroalgae measured by pulse amplitude modulated chlorophyll fluorometry and mass spectrometry. J Phycol 37:756-767

> Geel C, Versluis W, Snel JFH (1997) Estimation of oxygen evolution by marine phytoplankton from measurement of the efficiency of Photosystem II electron flow. Photosynth Res 51:61-70

Genty B, Briantais JM, Baker NR (1989) The relationship between the quantum yield of photosynthetic electron transport and quenching of chlorophyll fluorescence. Biochim Biophys Acta 990:87-92

Gévaert F, Créach A, Davoult D, Migné A and others (2003) Laminaria saccharina photosynthesis measured in situ: photoinhibition and xanthophyll cycle during a tidal cycle. Mar Ecol Prog Ser 247:43-50

Gilbert M, Wilhelm C, Ritcher M (2000) Biooptical modelling of oxygen evolution using in vivo fluorescence: comparison of measured and calculated photosynthesis/irradiance $(P-I)$ curves in four representative planktonic species. J Plant Physiol 157:307-314

Gómez I, López-Figueroa F, Ulloa N, Morales V, Lovengreen C, Huovinen P, Hess S (2004) Patterns of photosynthesis in 18 species of intertidal macroalgae from southern Chile. Mar Ecol Prog Ser 270:103-116

Green EJ, Carritt DE (1967) New tables of oxygen saturation of seawater. J Mar Res 25:140-147

> Häder DP, Lebert M, Figueroa FL, Jiménez C, Viñegla B, Perez-Rodriguez E (1998) Photoinhibition in Mediterranean macroalgae by solar radiation measured on site by PAM fluorescence. Aquat Bot 61:225-236

Hanelt D, Nultsch W (1991) The role of chromatophore arrangement in protecting the chromatophores of the brown alga Dictyota dichotoma against photodamage. J Plant Physiol 138:470-475

Hanelt D, Nultsch W (1995) Field studies of photoinhibition show non-correlations between oxygen and fluorescence measurements in the Arctic red alga Palmaria palmate. J Plant Physiol 145:31-38

Hanelt D, Wiencke C, Bischof K (2003) Photosynthesis in marine macroalgae. In: Larkum AW, Douglas SE, Raven JA (eds) Photosynthesis in algae. Kluwer Academic Publishers, Amsterdam, p 413-435

Køie M, Kristiansen A, Weitemeyer S (2000) Havets dyr og planter, 1st edn. Gads Forlag, Copenhagen

Krömer S (1995) Respiration during photosynthesis. Annu Rev Plant Physiol Plant Mol Biol 46:45-70

Kromkamp JC, Forster RM (2003) The use of variable fluorescence in aquatic ecosystems: differences between multiple and single turnover measuring protocols and suggested terminology. Eur J Phycol 38:103-112

Lavaud J, Gorkom HJ, Etienne AL (2002) Photosystem II electron transfer cycle and chlorespiration in planktonic diatoms. Photosynth Res 74:51-59

Lee RE (1999) Phycology, 2nd edn. Cambridge University Press, Cambridge

Lis R, Attaia A (2003) Control of mitochondrial function via photosynthetic redox signals. Photosynth Res 79:133-148

Longstaff BJ, Kildea T, Runcie JW, Cheshire A and others (2002) An in situ study of photosynthetic oxygen exchange and electron transport rate in the marine macroalgae Ulva lactuca (Chlorophyta). Photosynth Res 74:281-293

Maxwell K, Johnson GN (2000) Chlorophyll fluorescence-a practical guide. J Exp Bot 51:659-668
Nielsen HD, Nielsen SL (2005) Photosynthetic responses to $\mathrm{Cu}^{2+}$ exposure are independent of light acclimation and uncoupled from growth inhibition in Fucus serratus (Phaeophyceae). Mar Pollut Bull 51:715-721

Nultsch W, Pfau J (1979) Occurrence and biological role of light-induced chromatophore displacements in seaweeds. Mar Biol 51:77-82

Nultsch W, Pfau J, Rüffer U (1981) Do correlations exist between chromatophore arrangements and photosynthetic activity in seaweeds? Mar Biol 62:111-117

Osmond CB (1994) What is photoinhibition? Some insights from comparisons of shade and sun plants. In: Barker NR, Bowyer JR (eds) Photoinhibition of photosynthesis from molecular mechanisms to the field. BIOS Scientific Publishers, Oxford, p 1-24

Padmasree K, Padmavathi L, Raghavendra AS (2002) Essentiality of mitochondrial oxidative metabolism for photosynthesis: optimization of carbon assimilation and protection against photoinhibition. Crit Rev Biochem Mol Biol 37: 71-119

Peterson RB, Oja V, Laisk A (2001) Chlorophyll fluorescence at 680 and $730 \mathrm{~nm}$ and leaf photosynthesis. Photosynth Res 70:185-196

Prasil O, Kolber Z, Berry JA, Falkowski PG (1996) Cyclic electron flow around Photosystem II in vivo. Photosynth Res 48:395-410

Quinn GP, Keough MJ (2002) Experimental design and data analysis for biologists, 1st edn. Cambridge University Press, Cambridge

> Reddy MM, Vanti T, Raghavendra AS (1991) Light-enhanced dark respiration in mesophyll protoplasts from leaves of pea. Plant Physiol 96:1368-1371

Schreiber U, Hormann H, Asada K, Neubauer C (1995) $\mathrm{O}_{2}$ dependent electron flow in intact spinach chloroplasts: properties and possible regulation of the Mehlerascorbate peroxide cycle. In: Mathis P (ed) Photosynthesis: from light to biosphere. Kluwer Academic Publications, Amsterdam, p 813-818

Shibata K (1959) Spectrophotometry of translucent biological materials-opal glass transmission method. Methods Biochem Anal 7:77-109

Strain E, Beardall J, Thomson R, Roberts S, Light B (2006) Spatio-temporal variability in the photosynthetic characteristics of Zoestera tasmanica measured by PAM. Aquat Bot 85:21-28

Suggett DJ, Oxborough K, Baker NR, Macintyre HL, Kana TM, Geider RD (2003) Fast repetition and pulse modulation chlorophyll a fluorescence measurements for assessment of photosynthetic electron transport in marine phytoplankton. Eur J Phycol 38:371-384

Vogelmann TC (1993) Plant tissue optics. Annu Rev Plant Physiol Plant Mol Biol 44:231-251

> Wagner H, Jacob T, Wilhelm C (2006) Balancing the flow from captured light to biomass under fluctuating light conditions. New Phytol 169:95-108

White AJ, Critchley C (1999) Rapid light curves: a new fluorescence method to assess the state of the photosynthetic apparatus. Photosynth Res 59:63-72

> Williams WE, Gorton HL, Witiak SM (2003) Chloroplast movements in the field. Plant Cell Environ 26:2005-2014

> Wintermans JFGM, DeMots A (1965) Spectrophotometric characteristics of chlorophylls $a$ and $b$ and their pheophytins in ethanol. Biochim Biophys Acta 109:448-453 